\title{
PENGEMBANGAN MEDIA PEMBELAJARAN INTERAKTIF BERBASIS BLOG RIAS WAJAH SEHARI-HARI TATA KECANTIKAN KULIT
}

\author{
Dian Maya Sari dan Esther Restie Sipahutar \\ Jurusan Pendidikan Kesejahtaraan Keluaraga (PKK) FT Universitas Negeri Medan \\ dms.ab22@gmail.com
}

\begin{abstract}
Abstrak: Penelitian ini bertujuan untuk menghasilkan Media pembelajaran interaktif berbasis blog rias wajah sehari-hari tata kecantikan kulit yang layak digunakan. Penelitian pengembangan menggunakan model Borg \& Gall dikombinasikan dengan model ADDIE. Hasil penelitian menunjukkan bahwa: aspek kelayakan isi dinilai sangat baik dengan persentase $90 \%$. Pada aspek penyajian materi dinilai sangat baik dengan persentase nilai $98 \%$ dan pada aspek kebahasaan materi dinilai sangat baik dengan persentase $96 \%$. Secara keseluruhan validasi ahli materi dinilai sangat baik dengan persentase $94,6 \% \%$. Hasil validasi ahli media pada aspek kualitas penyajian media dinilai sangat baik dengan persentase $92 \%$ dan pada aspek desain media pembelajaran dinilai sangat baik dengan persentase $94 \%$. Secara keseluruhan validasi ahli media pembelajaran dinilai sangat baik dengan persentase nilai 93\%. Hasil uji coba lapangan pada siswa kelas X pada aspek kualitas materi pembelajaran dinilai baik dengan persentase nilai $88,6 \%$ dan pada aspek tampilan media pembelajaran dinilai sangat baik dengan persentase nilai 90,2\%. Data ini membuktikan bahwa penggunaan media pembelajaran interaktif berbasis blog lebih efektif dalam meningkatkan kompetensi dan pengetahuan siswa.
\end{abstract}

Kata Kunci: media pembelajaran, berbasis blog, rias wajah sehari-hari

\begin{abstract}
This research aims to produce media-based interactive learning blogs everyday makeup to skin care system that is fit for use. Research development model combined Borg \& Gall ADDIE model. The results showed that: the feasibility aspect of the content considered to be very good with a percentage of $90 \%$. At the presentation of the material aspect is considered very good by $98 \%$ and the percentage of the value of the linguistic aspects of the material considered to be very good with the percentage of $96 \%$. Overall validation of expert material considered to be very good with a percentage of $94.6 \% \%$. Media expert validation results on the quality aspects of presentation media is considered very good by $92 \%$ and the percentage of the instructional media design aspects considered to be very good with the percentage of $94 \%$. Overall validation of instructional media experts rated as excellent by the percentage value of $93 \%$. The results of field trials in class $\mathrm{X}$ on the quality aspect of learning materials is considered good by $88.6 \%$ and the percentage value on aspects of instructional media display rated excellent by the percentage value of $90.2 \%$. These data demonstrate that the use of media-based interactive learning blog more effective in improving students' competence and knowledge.
\end{abstract}

Keywords: learning media, based blog, everyday makeup

\section{PENDAHULUAN}

Sejak awal Tahun 2000 Ilmu Pengetahuan dan Teknologi (IPTEK) berkembang demikian pesat khususnya dalam bidang industri. Di satu sisi, era ini membawa iklim yang semakin terbuka untuk saling bekerja sama, saling mengisi dan saling melengkapi. Namun disisi lain, era ini juga membawa kepada persaingan yang sangat kompetitif. Sehubungannya dengan kondisi ini, banyak dunia kerja saat ini menuntut tenaga kerja yang siap pakai dan tenaga kerja yang memiliki pengetahuan dan keterampilan yang baik pada suatu bidang tertentu (Tirtarahardja, 2005).

Kondisi ini merupakan tantangan bagi dunia pendidikan khususnya Sekolah Menengah Kejuruan (SMK). Hal ini sesuai dengan Undang-Undang Sistem Pendidikan Nasional (UUSPN) (2004) yang menyebutkan bahwa 
pendidikan kejuruan merupakan pendidikan menengah yang mempersiapkan peserta didik terutama untuk bekerja dalam bidang tertentu (Tirtarahardja, 2005).

Sesuai dengan Kurikulum Tingkat Satuan Pendidikan (KTSP) SMK (2006), SMK memiliki tujuan untuk: 1) menyiapkan peserta didik agar menjadi manusia produktif, mampu bekerja mandiri, mengisi lowongan pekerjaan yang ada di dunia usaha dan dunia industry sebagai tenaga kerja tingkat menengah sesuai dengan kompetensi dalam program keahlian yang dipilihnya, 2) menyiapkan peserta didik agar mampu memilih karir, ulet dan gigih dalam berkompetensi, beradaptasi dilingkungan kerja, dan mengembangkan sikap professional dalam bidang keahlian yang diminatinya, 3) membekali peserta didik dengan kompetensikompetensi yang sesuai dengan program keahlian yang dipilihnya.

Untuk menyiapkan lulusan SMK menjadi tenaga yang produktif, adaptif dan kreatif, SMK Negeri 3 Pematang Siantar mempunyai tiga jenis mata pelajaran yang digolongkan menjadi: pelajaran normative, adaptif dan produktif. Kompetensi merias wajah sehari-hari adalah salah satu mata pelajaran produktif yang diterima siswa SMK bidang keahlian tata kecantikan. Pelajaran ini dapat mengantarkan siswa kepada dasar pemahaman program produktif lainnya seperti: Kompetensi rias wajah karakter, rias wajah panggung, rias wajah foto dan sebagainya. Kelemahan dalam memahami kompetensi rias wajah sehari-hari akan berdampak negative terhadap penguasaan program produktif lainnya

Permasalah yang sering terjadi pada siswa SMK Negeri 3 Pematang Siantar yaitu penggunaan media belajar yang masih rendah serta metode pengajaran yang diterapkan oleh guru hanya menggunakan metode ceramah. Guru hanya menyampaikan materi secara verbal tanpa ada hubungan interaktif dari siswa, selanjutnya media yang digunakan juga monoton, dimana media tersebut masih menggunakan media cetak seperti buku, majalah dan modul. Maka dari itu diperlikan variasi media pembelajaran yang dapat meningkatkan minat siswa terhadap materi pembelajaran.

Tidak tercapainya standar kompetensi pada mata pelajaran praktek, menyebabkan kurang tumbuhnya motivasi dan kreatifitas mahasiswa dalam proses belajar. Dalam hal ini terutama pada proses belajar rias wajah sehari- hari. Padahal, ilmu merias wajah khususnya kompetensi rias wajah sehari-hari merupakan pengetahuan yang harus dipahami dan diaplikasikan, bukan hanya berbentuk hafalan.

Materi rias wajah sehari-hari itu sendiri merupakan materi yang berkelanjutan dari satu kesatuan dan kompleks. Suatu teknik merias wajah, jika hanya diperoleh dengan membaca teori-teori dari buku cetak, tidak akan tersampaikan dengan jelas bagaimana maksud dan tujuannya. Teori-teori yang ada dalam buku atau modul tidak dapat menjadi sarana pembentukan kreatifitas dan kemandirian mahasiswa, karena mahasiswa tidak melihat secara langsung teknik aplikasi merias wajah secara tutorial. Selain itu, dengan hanya melihat buku atau modul saja daya serap mahasiswa tentunya tidak sama pada setiap orang, akan sangat kurang dalam memahami teknik atau aplikasi pangkas rambut dimaksud, dikarenakan tidak adanya contoh yang nyata. Sehingga, mengakibatkan mahasiswa tidak dapat berimajinasi untuk dapat menumbuhkan kreatifitas yang maksimal.

Novian (2005:64) semakin banyak tujuan pembelajaran yang bisa dibantu dengan media pembelajaran maka semakin baiklah proses belajar mengajar. Media yang baik juga akan mengaktifkan pembelajar dalam memberikan tanggapan, umpan balik dan juga mendorong pembelajar untuk melakuan praktikpraktik dengan benar.

Untuk menguasai kompetensi rias wajah sehari-hari, selain dengan praktek penguasaan teknik merias wajah itu sendiri, ada hal lain yang bersifat khusus yang sangat dibutuhkan. Yaitu, konsep diri, kreativitas, kemampuan berinovasi, inisiatif, estetika, kerajinan, kesabaran, ketelitian. Dimana kedelapan komponen tersebut tentu saja tidak semua siswa memilikinya. Siswa pada umumnya belajar rias wajah sehari-hari hanya sebagai satu topik pada kompetensi yang harus ditempuh, tanpa merasa harus mendalami kemampuan teori, konsep diri, bakat dan karakter sebagai seorang perias wajah.

Proses belajar mengajar rias wajah sehari-hari harus bertahap, berkelanjutan dan membutuhkan banyak latihan/job-sheet yang dapat dilakukan di ruang praktek sekolah atau di rumah. Dengan hanya belajar di sekolah, siswa tidak akan menjadi terampil dan mahir dalam kompetensi rias wajah sehari-hari ini. Siswa dituntut untuk dapat mengembangkan 
kreatifitas dan berinovasi dalam praktek rias wajah sehari-hari.

Berdasarkan hasil wawancara yang dilakukan oleh peneliti pada tanggal 18 Mei 2013 kepada guru rias wajah sehari-hari kelas $\mathrm{X}$, bahwasannya proses pembelajaran yang dilakukan pada saat ini masih dilakukan dengan cara metode ceramah, membaca buku, dan memperlihatkan gambar pada buku sebagai media pembelajaran, selain itu kemampuan peserta didik dalam kompetensi rias wajah sehari-hari juga kurang hal ini dapat dilihat dari hasil belajar siswa. Pada tahun ajaran 2009/2010 menyatakan bahwa sebanyak 60 persen siswa memperoleh nilai dibawah 70,33 persen siswa memperoleh nilai 70 dan dan hanya 6,7 persen memperoleh nilai 60 . Tahun ajara 2012/2011 terdapat peningkatan nilai siswa namu belum ada yang mencapai criteria penilaian 90. Hanya 9,6 persen memperoleh nilai $80,48,4$ persen memperoleh nilai 70 dan siswa yang memperoleh nilai dibawah 70 sebanyak 42 persen. Pada tahun 2011/2012 siswa yang memperoleh nilai 70 sebanyak 42 persen dan hanya 9,9 persen yang memperoleh nilai 80. Berdasarkan uraian tersebut masih ada siswa yang belum mencapai nilai ketuntasan (70).Di lain sisi, SMK Negeri 3 menyediakan fasilitas internet (wifi) dan komputer, maka dari itu sangat disayangkan jika fasilitas internet (wifi) tidak digunakan semaksimal mungkin untuk kegiatan belajar mengajar. Melihat kondisi ini, maka harus segera ada pilihan media pembelajaran yang informatif dan inovatif untuk memberdayakan siswa.

Menurut Hamalik (1994:6) menyatakan bahwa para guru dituntut agar mampu memahami, menggunakan alat-alat yang tersedia dalam upaya mencapai tujuan pembelajaran yang diharapkan.Untuk mencapai tujuan tersebut, guru dapat menggunakan media pembelajaran yang inovatif. Salah satu upaya yang dapat dilakukan untuk menyikapi persoalan dimaksud adalah dengan penggunaan media blog yang lebih baik sebagai media pembelajaran. Karena dimasa-masa mendatang internet akan semakin meningkat dengan adanya pembaharuan-pembaharuan teknologi pembelajaran, maka arus informasi akan semakin meningkat. Dengan demikian, kegiatan belajar mengajar tidak dapat terlepas dari keberadaan TIK dan Internet

Media pembelajaran interaktif berbasis blog memiliki beberapa keistimewaan seperti: 1) untuk memperjelas penyajian pesan agar tidak terlalu bersifat verbalostis, 2) mengatasi keterbatasan ruang, waktu dan daya indera, 3) dapat mengatasi sifat pasif anak didik dan, 4) mempermudah guru dalam menyampaikan materi pembelajaran. Guru tidak lagi perlu menyampaikan seluruh materi pembelajaran melalui ceramah, tetapi guru bertugas sebagai fasilitator dalam memecahkan kesulitankesulitan belajar yang dialami oleh siswa (Sukiman, 2012)

Dari pernyataan di atas, tersirat bahwa pengajar atau guru harus memiliki pengetahuan dan pemahaman yang cukup tentang media pembelajaran. Apalagi pada masa ini, dimana teknologi informasi sudah mengalami kemajuan pesat, suka tidak suka, para pengajar khususnya guru sudah seharusnya lebih membuka diri untuk berusaha menguasai teknologi informasi guna mendukung terciptanya proses belajar mengajar yang menarik, efisien dan tercapainya tujuan pembelajaran. Dalam hal ini, yang dimaksud media bukan hanya dalam bentuk buku teks atau cetak, tetapi sudah memanfaatkan perkembangan teknologi informasi yang beragam jenisnya, diantaranya dalam bentuk blog pembelajaran interaktif.

Perkembangan dunia teknologi informasi, khususnya komputerisasi sangat pesat dan mengagumkan. Dewasa ini, hampir semua bidang pekerjaan telah dapat dikendalikan oleh sistem komputer. Bahkan pekerjaan yang sulit dan membutuhkan tenaga ekstra sekarang dapat digantikan oleh sarana ini. Komputer dapat menerjemahkan teori-teori yang abstrak menjadi konkret dengan visualisasi statis maupun dengan visualisasi dinamis (animasi). Selain itu, komputer dapat membuat suatu konsep lebih menarik sehingga menambah motivasi untuk mempelajari dan memahaminya. Selain itu, banyak hal yang ingin diketahui oleh manusia, ada di dalam computer dan internet.

Menurut Rossie dan Breidle (2006) "Media pembelajaran adalah seluruh alat dan bahan untuk mencapai tujuan pendidikan seperti radio, buku, majalah dan sebagainya". Arsyad (2005) mengemukakan bahwa media pembelajar adalah sebagai bentuk-bentuk komunikasi baik tercetak maupun audio visual dan peralatannya, dengan demikian media dapat dimanipulasi, dilihat, didengar dan dibaca. "media pembelajaran adalah komponen sumber belajar atau wahana fisik yang mengandung materi instruksional dilingkungan siswa yang dapat merangsang siswa untuk belajar. 
Perbandingan perolehan hasil belajar melalui indera pandang dan indera dengar sangat menonjol perbedaannya, kurang lebih 90\% hasil belajar seseorang diperoleh melalui indera pandang dan hanya sekitar 5\% diperoleh melalui indera dengar dan 5\% lagi dengan indera lainnya (Arsyad, 2011). Jadi, agar proses belajar mengajar dapat berhasil dengan baik, siswa sebaiknya diajak untuk memanfaatkan semua alat indera yang mereka miliki. Guru berupaya untuk menampilkan rangsangan (stimulus) yang dapat diproses dengan berbagai alat indera. Semakin banyak alat indera yang digunakan untuk menerima dan mengolah informasi, maka semakin besar kemungkinan informasi tersebut dimengerti dan dapat dipertahankan dalam ingatan.

Dari uraian permasalahan di atas, peneliti tertarik untuk membuat suatu pengembangan media interaktif dalam pembelajaran dalam hal ini difokuskan pada blog pembelajaran interaktif pada kompetensi rias wajah sehari. Selain itu, kajian dari permasalahan di atas berdasarkan fakta yang ditemukan pada Jurusan Tata Kecantikan Kulit, menunjukkan bahwa pemanfaatan buku atau modul dalam mata pelajaran yang pada dasarnya adalah aplikasi praktek, sangat tidak membantu. Prodi Tata Kecantikan membutuhkan media pembelajaran interaktif nernasis blog, yang mana dalam hal ini peneliti melakukan penelitian pada satu mata pelajaran yang sesuai dengan keahlian peneliti yakni mata pelajaran Rias Wajah Sehari-hari.

Peneliti melihat, bahwa pengembangan blog interaktif untuk pembelajaran Rias Wajah Sehari-hari merupakan alternatif yang tepat dalam proses belajar mengajar. Pemanfaatan teknologi informasi dalam bentuk blog yang dilengkapi dengan fitur-fitur gambar animasi yang menarik, dapat membuat suasana belajar mengajar berlangsung menarik dan tercipta proses pembelajaran yang tidak berkesan monoton dan membosankan, serta mudah dipahami. Selain itu juga dapat membantu daya tangkap siswa terhadap materi yang akan disampaikan. Dengan demikian, mahasiswa dapat belajar secara mandiri dan dapat berkreatifitas sesuai dengan bakat dan minatnya.

Belajar adalah kegiatan yang dilakukan oleh seseorang agar memiliki kompetensi berupa keterampilan dan pengetahuan yang diperlukan. Menurut Gagne (1983:49)" A natural process that leads to changes in what we know, what we can do, and how we behave. Pengertian belajar di atas senada dengan apa yang diungkapkan oleh Kingsley dalam Ahmadi dan Supriono (2008:127), Learning is the by which behavior in the broader sense is originated or changed through practice or training. Diartikan belajar adalah proses dimana tingkah laku (dalam arti luas) ditimbulkan atau diubah melalui praktek atau latihan. Selanjutnya Meyer, Smith \& Ragan dalam Pribadi (2009:4) belajar sebagai perubahan yang relatif permanen dalam pengetahuan dan perilaku seseorang yang diakibatkan oleh pengalaman.

Heinich et.al.

(1996:17) mengemukakan bahwa teori belajar konstruktivisme merupakan teori belajar yang menekankan pada pengalaman mahasiswa, tidak semata pengetahuan kognitif. Teori konstruktivisme ini membantu mahasiswa mentrasformasikan informasi dalam pembelajaran dan membangun pengetahuan mahasiswa dengan sendiri melalui keterlibatan secara aktif dalam proses pembelajaran.

Senada dengan pendapat Wedemeyer (dalam Srililis, 2008:5) Kemandirian dalam belajar perlu diberikan kepada peserta didik supaya mereka mempunyai tanggung jawab dalam mengatur dan mendisiplinkan dirinya dan dalam mengembangkan kemampuan belajar atas kemauan sendiri. Sikap-sikap tersebut perlu dimiliki peserta didik karena hal tersebut merupakan ciri kedewasaan orang terpelajar.

Pusat Pengembangan dan Pemberdayaan Pendidikan dan Tenaga Kependidikan Bidang Bisnis dan Pariwisata Jakarta (P4TK, 2009:4) mendefinisikan kata dasar pangkas adalah "pangkas" yang artinya potong. Pangkas rambut adalah tindakan memotong rambut atau mengurangi panjang rambut semula, sedangkan pangkas rambut lanjutan adalah suatu tindakan mengurangi panjang rambut dengan berbagai teknik, sudut pengangkatan dan alat pangkas sesuai keinginan, karakteristik pelanggan dan dikembangkan sesuai dengan perkembangan dan trendcenter yang sedang berkembang saat ini.

Menurut Astati (1995) rias wajah sehari-hari adalah seni mempercantik diri atau orang lain dengan menggunakan kosmetika dengan cara mengoreksi bagian-bagian wajah yang kurang sempurna agar terlihat lebih sempurna. Tujuan rias wajah sehari-hari adalah: a) mengoreksi bentuk wajah dan bagian-bagian wajah agar lebih mendekati kebentuk yang 
ideal, b) wajah terlihat lebih sehat, segar dan cantik.

Prinsip-prinsip rias wajah sehari-hari adalah: a) warna alas bedak sama dengan warna kulit, b) lakukan tata rias wajah koreksi untuk memperoleh tampilan wajah yang ideal sesuai dengan keinginan dan kesempatan, c) relief wajah yang baik hendaknya memberI kesan kedalaman pada wajah, dengan menggunakan warna kosmetik seperti warna bayangan, warna pemerah pipi dan warna pemerah bibir yang sebaiknya serasi dengan warna kelopak mata, warna kulit dan warna busana (Kusianti, 2011)

Menurut Hakim (1998) prosedur rias wajah sehari-hari adalah: 1) lakukan tata rias wajah koreksi, 2) bersihkan seluruh permukaan wajah dengan susu pembersih atau milk cleanser, lalu berikan penyegar sesuai dengan jenis kulit untuk menyegarkan dan menutupi pori-pori kulit, 3) berikan pelembap tipis pada wajah dan leher agar kulit wajah tetap terjaga kelembapannya, 4) aplikasikan stick foundation warna gelap untuk menutupi noda pada wajah atau untuk menyamarkan noda pada wajah, 5) aplikasikan alas bedak secara merata menggunakan spons yang lembap, 6) bubuhkan bedak tabor menggunakan spons bedak tabor. Setelah bedak tabor, aplikasikan bedak padat, 7) bentuk alis mata, lalu aplikasikan perona mata (eye shadow) yang memiliki warna yang lembut atau soft seperti warna pastel, merah muda, coklat muda, setelah itu aplikasikan sipat mata (eye liner) yang berguna untuk mempertegas garis mata, setelah itu aplikasikan mascara pada bulu mata, agar bulu mata terlihat tebal dan panjang, 8) bubuhkan perona pipi, 9) bingkai bentuk bibir dengan pensil bibir atau lipliner lalu oleskan pewarna bibir dengan rapi dan merata.

Rusijono dkk (2008:39) penelitian pengembangan adalah kegiatan yang menghasilkan rancangan atau produk yang dapat dipakai untuk memecahkan masalah aktual. Dalam hal ini, kegiatan pengembangan ditekankan pada pemanfaatan teori, konsep, prinsip atau temuan penelitian untuk memecahkan masalah. Pengembangan (development) merupakan proses penterjemahan spesifikasi rancangan menjadi bentuk fisik. Seels \& Richey (1994:35) mendeskripsikan pengembangan sebagai: (a) pesan yang terkandung didalam isi, (b) strategi pembelajaran yang mengandung teori dan (c) perwujutan dari teknologi berupa perangkat keras dan lunak serta bahan-bahan media pembelajaran. Terkait dengan pengembangan ini, Miarso (2004:419) mengemukakan bahwa bila dikaji secara empiris, pengembangan adalah cara yang dilakukan dengan menciptakan sesuatu model terbatas yang diawasi secara cermat terlebih berbagai komponen pengembangan dicobakan, dinilai dan disempurnakan.

Perancangan produk dilakukan dengan menggunakan model desain pembelajaran ADDIE (Analisis, Design, Devolopment, Implementation, Evaluation), dengan menggunakan model dalam pembelajaran ADDIE . Pemilihan model ini berdasarkan atas pertimbangan pada model pengembangan yang disusun secara terprogram dengan langkahlangkah persiapan dan perencanaan yang dalam hal ini penulis menyesuaikan sesuai dengan judul media pembelajaran interaktif pada kompetensi rias wajah sehari-hari meliputi 3 tahap atau 3 langkah pokok yang mana dari ketiga langkah tersebut harus sistematik dan beruntun diantaranya sebagai berikut: (1) pengembangan desain pembelajaran yang meliputi : (a) identifikasi kebutuhan Instruksional \& menulis standart kompetensi, (b) melakukan analisis pembelajaran, (c) mengidentifikasi karakteristik dan perilaku awal siswa, (d) menulis kompetensi dasar serta indikatornya, (e) menulis tes acuan patokan, (f) menyusun strategi pembelajaran, (g) mengembangkan bahan ajar, (h) mendesain evaluasi formatif, (2) pengembangan desain blog pembelajaran yang meliputi: (a) membuat flowchart, (b) membuat stroryboard, (c) pembuatan naskah, (d) pengumpulan bahan pembuatan video, (e) pembuatan produk awal, (3) validasi, uji coba dan revisi, produk akhir yang meliputi: (a) validasi ahli media dan materi, (b) revisi I, (c) uji coba perorangan, (d) revisi II, (e) uji coba lapangan, (f) revisi III, (g) prodak akhir video pembelajaran pangkas rambut lanjutan.

Berdasarkan temuan M.Ilham Akbar bersama-sama dengan M,Arief Furqon dan Maya Retno Ayu Setyautami (2010) dari fakultas Ilmu Komputer Universitas Indonesia ada 3 metode yang bisa diupayakan untuk menggunakan blog sebagai media pembelajaran, yaitu :a) Blog guru sebagai pusat pembelajaran. Guru dapat menuliskan materi belajar, tugas maupun bahan diskusi di blognya, kemudian para murid dapat berdiskusi dan belajar bersama di blog gurunya tersebut, b) Blog guru dan murid yang saling berinteraksi. 
Guru, yang harus memiliki blog, mengharuskan murid memiliki blog-nya masing-masing, sebagai sarana mengerjakan tugas-tugas yang diberikan oleh gurunya. Metode ini bidsa memacu iklim kompetisi antar siswa, karena tentu saja para siswa ingin blog nya menjadi yang terbaik, c) Komunitas blog pembelajaran. Ada sebuah blog sebagai pusat pembelajaran (bisa berupa blog aggregator atau blog dengan beberapa contributor). Dengan guru-guru dan siswa dari berbagai sekolah bisa tergabung dalam komunitas blogger pembelajaran tersebut

Menurut Sukiman, dalam Buku Pengembangan Media Pembelajaran (2012) perkembangan dapat menyebabkan adanya perubahan metode konvensional dalam proses belajar mengajar yang digantikan dengan metode e-learning. Metode conventional learning yang mengharuskan guru dan siswa harus bertatap muka langsung diruang kelas memiliki beberapa ciri, yaitu: 1) pembelajaran tergantung pada guru, 2) seluruh kegiatan belajar mengajar terpusat di dalam kelas, 3) guru merupakan sumber ilmu, 4) dibatasi jarak, ruang dan waktu; dan 5) harus memiliki sarana prasana belajar mengajar yang memadai serta sumber saya guru yang memahami setiap materi yang diajarkan. Sedangkan ciri-ciri pembelajaran yang menggunakan blogger adalah: 1) pembelajaran tidak tergantung kepada guru, 2) banyaknya sumber materi dan kemudahan akses; 3) peran guru hanya sebagai mediator dan pembimbing; 4) proses belajar tidak terkendala jarak, ruang dan waktu.

Adapun manfaat atau kegunaan media itu sendiri menurut uraikan oleh Harsja (2009:17) antara lain: (1) memperjelas penyajian pesan agar tidak terlalu bersifat verbalistis (tertulis atau lisan), (2) mengatasi keterbatasan ruang, waktu dan daya indera seperti: (a) objek yang terlalu besar dapat digantikan dengan realita gambar, film bingkai atau model, (b) objek yang kecil dibantu dengan proyektor mikro, film bingkai dan gambar, (c) gerak yang terlalu lambat atau cepat dapat dibantu dengan timelapse atau high speed photography, (d) kejadian atau peristiwa yang terjadi dimasa lalu bisa ditampilkan lagi lewat rekaman film, video film bingkai, foto maupun secara verbal, (e) objek yang terlalu kompleks (misalnya mesin-mesin) dapat disajikan dengan model, diagram, (f) konsep yang terlalu luas dapat divisualkan dalam bentuk film, gambar atau film bingkai, (3) penggunaan media pendidikan secara tepat dan bervariasi dapat mengatasi sikap pasif anak didik, (4) dengan sifat yang unik pada tiap siswa ditambah dengan lingkungan dan pengalaman yang berbeda, sedangkan kurikulum dan materi pendidikan ditentukan sama untuk setiap siswa maka guru banyak mengalami kesulitan bilamana semuanya itu harus di atasi sendiri.

Penelitian dan pengembangan ini bertujuan untuk meghasilkan media pembelajaran interaktif berbasis blog tata rias berkualitas layak dijadikan acuan bagi mahasiswa dan orang umum, mudah dipelajari, dipahami dan dapat dipergunakan secara individual

\section{METODE}

Penelitian ini dilaksanakan di SMK Negeri 3 Pematang Siantar Jurusan Tata Kecantikan Kulit. Dalam penelitian dan pengembangan ini model yang akan dikembangkan mengacu kepada Research and Developmen (R\&D) dari model Borg \& Gall (1983) yang memiliki tujuan untuk mengembangkan dan memvalidasi produk dengan perencanaan pembelajaran dalam pengembangan blog pembelajaran ADDIE.

Proses pengembangan media blog pembelajaran ini dilakukan dengan prosedur sebagai berikut: (1) Pengumpulan informasi mengenai proses kegiatan pembelajaran dan permasalahan yang dihadapi, serta pengumpulan materi yang akan diimplementasikan ke dalam produk penelitian, (2) Perencanaan. Perencanaan berguna untuk menyusun dan mengumpulkan teori yang akan digunakan dalam mengembangkan produk, perencaan disusun berdasarkan dari materi pembelajaran yang telah ditetapkan oleh pihak sekolah seperti RPP ata Silabus, mengembangkan bahan pembelajaran, (4) Setelah materi terkumpul media pembelajaran blog interaktif mulai dibuat dengan cara: masuk kedalam aplikasi google karena aplikasi blog didukung penuh oleh google, jadi apabila kita membuat blog maka aplikasi google dapat mengindeks blog. Maka dari itu, cara pertama daftarkan akun pada aplikasi google yang telah disediakan. Lalu isi kolom password dan klik kolom control panel setelah itu lakukan pemilihan bahasa, lalu klik tanda panah besar yang bertuliskan "ciptakan blog anda". Setelah login pada aplikasi blog klik tombol buat akun yang terdapat di pojok atas. Pada tampilan buat akun isi kolom identitas diri seperti nama depan, nama belakang, tanggal lahir, nomor 
telpon dan alamat blog yang akan digunakan. Klik check box apabila menyetujui persyaratan layanan privasi google.klik tombol langkah berikutnya untuk melanjutkan pembuatan akun. Lalu pada tampilan blog berikan nama pada judul blog yang akan digunakan pada text book judul. Untuk memasukkan gambar pembelajaran pada blog, jenis gambar yang akan di masukan harus berupa jpg atau gif. Pertamatama, gambar di upload ke dalam aplikasi blog setelah itu pada klik kolom masukan gambar, setelah gambar tersebut maasuk kedalam aplikasi blog pilih. Lalu masukkan video pembelajaran kedalam blog debngan cara klik tombol insert a video lalu klik tombol unggah untuk memulai menyisipkan video ke dalam postingan blog. Lalu cara melampirkan materi pembelajaran dengan cara, klik kolom insert entry lalu klik tombol unggah dan pilih folder materi yang akan di lampirkan. Setelah itu pembuatan link kuis interaktif pada blog pembelajaran dengan cara klik download APK kemudian klik link pada tool bar lalu ketik link yang akan dihubungkan lalu klik web address. Agar blog pembelajaran menarik aplikasikan warna dan musuk yang tepat pada kolom design blog lalu isi kolom warna dan masukan kode musik pada kolom musik, (5) Validasi blog pembelajaran dilakukan kepada 2 validasi materi pembelajaran dan 2 validasi media pembelajaran validasi dilakukan untuk mendapatkan saran dan masukan yang sesuai dengan bidangnya masing-masing dan kemudian di analisis dan disimpulkan, (6) Revisi produk dilakukan apabila produk yang dikembangkan belum valid dan masih membutuhkan revisi untuk kesempurnaan blog pembelajaran, (7) Apabila produk sudah valid, uji coba tahap 1 dilakukan pada siswa kelas $\mathrm{X}$ tata kecantikan kulit SMK Negeri 3 Pematang Siantar, (8) Revisi produk dilakukan apabila pada tahap uji coba lapangan tidak valid atau belum layak untuk digunakan, (9) Setelah hasil uji coba lapangan di nyatakan valid lalu produk disisipkan pada blog pembelajaran sekolah SMK Negeri 3 Pematang Siantar.

Uji coba dimaksudkan untuk mengumpulkan data dalam rangka evaluasi formatif yang dijadikan dasar dalam menempatkan apakah produk tersebut telah benar-benar layak digunakan dan menarik. Kegiatan yang dilakukan pada tahap desain uji coba adalah sebagai berikut: a) Validasi ahli materi Rias Wajah Sehari-hari, b) Validasi ahli media/pembelajaran, c) Analisis konseptual, d) Revisi pengembangan, berdasarkan penilaian yang berupa masukan, kritik, atau saran dari ahli materi dan dari ahli media untuk dilakukan perbaikan, e) uji coba lapangan terhadap siswa, f) Penelitian mengenai daya tarik dan kelayakan produk, g) Analisis empirik (tahap II), h) Revisi kecil.

Peneliti mempergunakan instrumen angket berjenis angket tertutup kerena memiliki keuntungan bagi kedua belah pihak, bagi responden keuntungan yang diperoleh dapat dengan cepat mengisi dan praktis karena tinggal memilih jawaban yang telah disediakan sedangkan bagi peneliti keuntungan yang diperoleh yakni memudahkan dalam menganalisa dan menginterprestasikan data. Instrumen yang digunakan dalam penelitian ini adalah (1) lembar angket untuk ahli materi, (2) lembar angket untuk ahli media, (3) lembar angket untuk siswa.

Analisis data dalam penelitian ini menggunakan analisis deskriptif kuantitatif, semua data yang terkumpul dianalisis dengan teknik statistik deskriptif yang secara kuantitatif dipisahkan menurut kategori untuk mempertajam penilaian dalam menarik kesimpulan. Data kualitatif yang berupa pernyataan sangat kurang baik, cukup, sedang dan sangat baik diubah menjadi data kuantitatif dengan skala nilai 1 sampai 5. Hasilnya diratarata dan digunakan untuk menilai kualitas media blog pembelajaran. Kriteria media blog akan dikonversikan menjadi nilai dengan skala lima menggunakan skala Likert yang dinamis secara deskriptif persentase. Dalam penelitian ini data yang diperoleh adalah hasil belajar siswa dari kelas.

\section{HASIL DAN PEMBAHASAN \\ Hasil}

Hasil penilaian produk pembelajaran berdasarkan ahli materi pembelajaran menunjukan bahwa: (a) kualitas materi pembelajaran dinilai sangat baik dengan persentase rata-rata sebesar $90 \%$, (b) kualitas penyajian pembelajaran dinilai sangat baik dengan persentase rata-rata sebesar $98 \%$, dan (c) kualitas kebahasaan dinilai sangat baik dengan persentase rata-rata sebesar $96 \%$. Dengan demikian media pembelajaran interaktif berbsasis blog pada kompetensi rias wajah sehari-secara keseluruhan termasuk dalam kategori "sangat baik". 
Ahli media pembelajaran menyatakan (a) kualitas penyajian media pembelajaran dinilai sangat baik dengan persentase nilai $92 \%$, dan (b) kualitas desai media pembelajaran dinilai sangat baik dengan persentase nilai $94 \%$.
Berdasarkan uji coba lapangan aspek kualitas materi pembelajaran dinilai dengan persentase rata-rata sebesar $88,66 \%$ dan aspek tampilan media pembelajaran dinilai dengan persentase $91,88 \%$.

Tabel 1. Skor Penilaian Media Pembelajaran Interaktif Berbasis Blog Pada Ahli MaterI Pembelajaran Pada Aspek Penyajian Materi.

\begin{tabular}{|c|c|c|c|c|}
\hline No & Indikator Penilaian & Jawaban & $\mathbf{n}$ & $\%$ \\
\hline \multirow[t]{2}{*}{1} & \multirow[t]{2}{*}{$\begin{array}{l}\text { Kesesuaian dan ketepatan materi } \\
\text { dengan kompetensi }\end{array}$} & $\begin{array}{l}\text { 1. Cukup } \\
\text { 2. Setuju } \\
\text { 3. Sangat setuju }\end{array}$ & 2 & 100 \\
\hline & & Jumlah & 2 & 100 \\
\hline \multirow[t]{2}{*}{2} & \multirow[t]{2}{*}{$\begin{array}{l}\text { Ketepatan cakupan materi dengan } \\
\text { kompetensi }\end{array}$} & $\begin{array}{l}\text { 1. Cukup } \\
\text { 2. Setuju } \\
\text { 3. Sangat setuju }\end{array}$ & 2 & 100 \\
\hline & & Jumlah & 2 & 100 \\
\hline \multirow[t]{2}{*}{3} & \multirow[t]{2}{*}{ Kesesuaian konsep dengan materi } & $\begin{array}{l}\text { 1. Cukup } \\
\text { 2. Setuju } \\
\text { 3. Sangat setuju }\end{array}$ & $\begin{array}{l}1 \\
1\end{array}$ & $\begin{array}{l}50 \\
50\end{array}$ \\
\hline & & Jumlah & 2 & 100 \\
\hline \multirow[t]{2}{*}{4} & \multirow[t]{2}{*}{ Kedalaman materi pembelajaran } & $\begin{array}{l}\text { 1. Setuju } \\
\text { 2. Sangat setuju }\end{array}$ & 2 & 100 \\
\hline & & Jumlah & 2 & 100 \\
\hline \multirow[t]{2}{*}{5} & \multirow[t]{2}{*}{ Kesesuaian dengan kurikulum } & $\begin{array}{l}\text { 1. Cukup } \\
\text { 2. Setuju } \\
\text { 3. Sangat setuju }\end{array}$ & $\begin{array}{l}1 \\
1\end{array}$ & $\begin{array}{l}50 \\
50\end{array}$ \\
\hline & & Jumlah & 2 & 100 \\
\hline \multirow[t]{2}{*}{6} & \multirow[t]{2}{*}{$\begin{array}{l}\text { Ketepatan urutan penyampaian materi } \\
\text { pembelajaran }\end{array}$} & $\begin{array}{l}\text { 1. Setuju } \\
\text { 2. Sangat setuju }\end{array}$ & 2 & 100 \\
\hline & & Jumlah & 2 & 100 \\
\hline
\end{tabular}

Tabel 2. Skor Penilaian Media Pembelajaran Interaktif Berbasis Blog Pada Ahli MaterI Pembelajaran Pada Aspek Kebahasaan Pembelajaran.

\begin{tabular}{|l|l|l|c|c|}
\hline \multirow{2}{*}{ No } & \multicolumn{1}{|c|}{ Indikator Penilaian } & \multicolumn{1}{|c|}{ Jawaban } & n & \% \\
\hline 1 & Bahasa yang digunakan sederhana & $\begin{array}{l}\text { 1. Cukup } \\
\text { 2. Setuju } \\
\text { 3. Sangat setuju }\end{array}$ & 1 & 50 \\
\cline { 3 - 5 } & & Jumlah & 2 & 100 \\
\hline 2 & $\begin{array}{l}\text { Ketercernaan materi dan pemaparan } \\
\text { logis }\end{array}$ & $\begin{array}{l}\text { 1. Setuju } \\
\text { 2. Sangat setuju }\end{array}$ & 2 & 100 \\
\cline { 3 - 5 } & Jumlah & 2 & 100 \\
\hline 3 & $\begin{array}{l}\text { Bahasa yang digunakan mudah } \\
\text { dipahami }\end{array}$ & $\begin{array}{l}\text { 1. Setuju } \\
\text { 2. Sangat setuju }\end{array}$ & 2 & 100 \\
\cline { 3 - 5 } & Jumlah & 2 & 100 \\
\hline
\end{tabular}

Tabel 3. Skor Penilaian Media Pembelajaran Interaktif Berbasis Blog Pada Ahli Media Pembelajaran Pada Aspek Penyajian Media Pembelajaran

\begin{tabular}{|l|l|l|l|l|}
\hline No & Indikator Penilaian & Jawaban & n & $\%$ \\
\hline
\end{tabular}




\begin{tabular}{|c|c|c|c|c|}
\hline No & Indikator Penilaian & Jawaban & n & $\%$ \\
\hline \multirow{2}{*}{1} & \multirow{2}{*}{$\begin{array}{l}\text { Materi disajikan secara sederhana dan } \\
\text { jelas }\end{array}$} & 1. Sangat setuju & 2 & 100 \\
\hline & & Jumlah & 2 & 100 \\
\hline \multirow[t]{3}{*}{2} & \multirow{3}{*}{$\begin{array}{l}\text { Materi disajikan secara runtut yakni } \\
\text { dari sederhana ke kompleks dan dari } \\
\text { umum ke khusus }\end{array}$} & 4. Setuju & 1 & 50 \\
\hline & & 5. Sangat setuju & 1 & 50 \\
\hline & & Jumlah & 2 & 100 \\
\hline \multirow[t]{2}{*}{3} & \multirow[t]{2}{*}{ Menarik untuk dipelajari } & 1. Sangat setuju & 2 & 100 \\
\hline & & Jumlah & 2 & 100 \\
\hline \multirow[t]{3}{*}{4} & \multirow[t]{3}{*}{ Penyajian materi interaktif } & 4. Setuju & 1 & 50 \\
\hline & & 5. Sangat setuju & 1 & 50 \\
\hline & & Jumlah & 2 & 100 \\
\hline \multirow[t]{2}{*}{5} & \multirow[t]{2}{*}{ Gambar dan materi sesuai } & 5. Sangat setuju & 2 & 100 \\
\hline & & Jumlah & 2 & 100 \\
\hline \multirow[t]{3}{*}{6} & \multirow{3}{*}{$\begin{array}{l}\text { Penggunaan teks yang berbeda untuk } \\
\text { menandai bagian yang penting }\end{array}$} & 4. Setuju & 1 & 50 \\
\hline & & 5. Sangat setuju & 1 & 50 \\
\hline & & Jumlah & 2 & 100 \\
\hline \multirow[t]{3}{*}{7} & \multirow[t]{3}{*}{ Penjelasan istilah } & 4. Setuju & 1 & 50 \\
\hline & & 5. Sangat setuju & 1 & 50 \\
\hline & & Jumlah & 2 & 100 \\
\hline \multirow[t]{2}{*}{8} & \multirow[t]{2}{*}{ Bahasa yang digunakan sederhana } & $\begin{array}{l}\text { 4. Setuju } \\
\text { 5. Sangat setuju }\end{array}$ & 2 & 100 \\
\hline & & Jumlah & 2 & 100 \\
\hline \multirow[t]{3}{*}{9} & \multirow{3}{*}{$\begin{array}{l}\text { Ketercernaan materi dan pemaparan } \\
\text { logis }\end{array}$} & 4. Setuju & 1 & 50 \\
\hline & & 5. Sangat setuju & 1 & 50 \\
\hline & & Jumlah & 2 & 100 \\
\hline
\end{tabular}

Tabel 4. Skor Penilaian Media Pembelajaran Interaktif Berbasis Blog Pada Ahli Media Pembelajaran Pada Aspek Kegrafikan Media Pembelajaran

\begin{tabular}{|c|c|c|c|c|}
\hline No & Indikator Penilaian & Jawaban & $\mathbf{n}$ & $\%$ \\
\hline \multirow[t]{2}{*}{1} & \multirow{2}{*}{$\begin{array}{l}\text { Ketepatan komposisi warna yang } \\
\text { digunakan }\end{array}$} & 5. Sangat setuju & 2 & 100 \\
\hline & & Jumlah & 2 & 100 \\
\hline \multirow[t]{2}{*}{2} & \multirow{2}{*}{$\begin{array}{l}\text { Gambar ilustrasi sesuai dengan } \\
\text { konsepnya }\end{array}$} & 5. Sangat setuju & 2 & 100 \\
\hline & & Jumlah & 2 & 100 \\
\hline \multirow[t]{3}{*}{3} & \multirow[t]{3}{*}{ Mudah dipahami } & 4. Setuju & 1 & 50 \\
\hline & & 5. Sangat setuju & 1 & 50 \\
\hline & & Jumlah & 2 & 100 \\
\hline \multirow[t]{3}{*}{4} & \multirow[t]{3}{*}{ Jenis huruf dan ukuran dapat dibaca } & 4. Setuju & 1 & 50 \\
\hline & & 5. Sangat setuju & 1 & 50 \\
\hline & & Jumlah & 2 & 100 \\
\hline \multirow[t]{2}{*}{5} & \multirow{2}{*}{$\begin{array}{l}\text { Gambar perbandingan huruf antara } \\
\text { judul, subjudul, dan naskah sudah } \\
\text { proporsional. }\end{array}$} & $\begin{array}{l}\text { 4. Setuju } \\
\text { 5. Sangat setuju }\end{array}$ & 2 & 100 \\
\hline & & Jumlah & 2 & 100 \\
\hline \multirow[t]{2}{*}{6} & \multirow{2}{*}{$\begin{array}{l}\text { Ketepanan pemilihan musik dan } \\
\text { backsound }\end{array}$} & 5. Sangat setuju & 2 & 100 \\
\hline & & Jumlah & 2 & 100 \\
\hline \multirow[t]{2}{*}{7} & \multirow[t]{2}{*}{ Mudah di akses } & 5. Sangat setuju & 2 & 100 \\
\hline & & Jumlah & 2 & 100 \\
\hline
\end{tabular}

Tabel 5. Skor Penilaian Media Pembelajaran Interaktif Berbasis Blog Pada Siswa Aspek Penyajian Materi Pada Media Pembelajaran.

\begin{tabular}{|l|l|l|c|c|}
\hline No & \multicolumn{1}{|c|}{ Pernyataan } & \multicolumn{1}{|c|}{ Jawaban } & n & \% \\
\hline 1. & Kesesuaian dan ketepatan materi & 3. Cukup & 4 & 14,3 \\
\hline
\end{tabular}




\begin{tabular}{|c|c|c|c|c|}
\hline No & Pernyataan & Jawaban & $\mathbf{n}$ & $\%$ \\
\hline & & 4. Setuju & 7 & 25,0 \\
\hline & & 5. Sangat setuju & 17 & 60,7 \\
\hline & & Jumlah & 28 & 100 \\
\hline \multirow[t]{4}{*}{2.} & \multirow[t]{4}{*}{ Kejelasan petunjuk belajar } & 3. Cukup & 3 & 10,7 \\
\hline & & 4. Setuju & 17 & 60,7 \\
\hline & & 5. Sangat setuju & 8 & 28,6 \\
\hline & & Jumlah & 28 & 100 \\
\hline \multirow[t]{4}{*}{3.} & \multirow{4}{*}{$\begin{array}{l}\text { Kemudahan memahami kalimat pada } \\
\text { teks }\end{array}$} & 3. Cukup & 4 & 14,2 \\
\hline & & 4. Setuju & 12 & 42,9 \\
\hline & & 5. Sangat setuju & 12 & 42,9 \\
\hline & & Jumlah & 28 & 100 \\
\hline \multirow[t]{4}{*}{4.} & \multirow[t]{4}{*}{ Ketepatan urutan penyajian } & 3. Cukup & 2 & 07,2 \\
\hline & & 4. Setuju & 8 & 28,6 \\
\hline & & 5. Sangat setuju & 18 & 64,2 \\
\hline & & Jumlah & 28 & 100 \\
\hline \multirow[t]{4}{*}{5.} & \multirow[t]{4}{*}{ Kecukupan Latihan } & 3. Cukup & 5 & 17,8 \\
\hline & & 4. Setuju & 9 & 32,2 \\
\hline & & 5. Sangat setuju & 14 & 50,0 \\
\hline & & Jumlah & 28 & 100 \\
\hline \multirow[t]{4}{*}{6.} & \multirow[t]{4}{*}{ Kejelasan umpan balik } & 3. Cukup & 5 & 17,8 \\
\hline & & 4. Setuju & 7 & 25,0 \\
\hline & & 5. Sangat setuju & 16 & 57,2 \\
\hline & & Jumlah & 28 & 100 \\
\hline \multirow[t]{4}{*}{7.} & \multirow[t]{4}{*}{ Kemudahan di akses melalui internet } & 3. Cukup & 3 & 10,7 \\
\hline & & 4. Setuju & 3 & 10,7 \\
\hline & & 5. Sangat setuju & 22 & 78,6 \\
\hline & & Jumlah & 28 & 100 \\
\hline
\end{tabular}

Tabel 6. Skor Penilaian Media Pembelajaran Interaktif Berbasis Blog Pada Siswa Aspek Tampilan Media Pembelajaran.

\begin{tabular}{|l|l|l|c|c|}
\hline No & \multicolumn{1}{|c|}{ Pernyataan } & \multicolumn{1}{|c|}{ Jawaban } & n & \% \\
\hline \multirow{2}{*}{1.} & Keindahan tampilan warna & 4. Setuju & 6 & 21,4 \\
& & 5. Sangat setuju & 22 & 78,6 \\
\cline { 3 - 5 } & & \multicolumn{1}{|c|}{ Jumlah } & 28 & 100 \\
\hline 2. & \multirow{2}{*}{ Keterbacaan teks } & 3. Cukup & 7 & 25,0 \\
& & 4. Setuju & 4 & 14,3 \\
& & 5. Sangat setuju & 17 & 60,7 \\
\cline { 3 - 5 } & & Jumlah & 28 & 100 \\
\hline 3. & Kualitas gambar dan animasi & 3. Cukup & 1 & 03,6 \\
& & 4. Setuju & 6 & 21,4 \\
& & 5. Sangat setuju & 21 & 75,0 \\
\cline { 3 - 5 } & & Jumlah & 28 & 100 \\
\hline 4. & \multirow{2}{*}{ Komposisi warna } & 3. Cukup & 1 & 03,6 \\
& & 4. Setuju & 6 & 21,4 \\
& & 5. Sangat setuju & 21 & 75,0 \\
\cline { 3 - 5 } & & Jumlah & 28 & 100 \\
\hline 5. & \multirow{2}{*}{ Navigasi } & 3. Cukup & 2 & 07,1 \\
& & 4. Setuju & 5 & 17,8 \\
& & 5. Sangat setuju & 21 & 75,0 \\
\cline { 3 - 5 } & & Jumlah & 28 & 100 \\
\hline 6. & Daya dukung music & 3. Cukup & 2 & 07,1 \\
& & 4. Setuju & 8 & 28,6 \\
& & 5. Sangat setuju & 18 & 64,3 \\
\hline
\end{tabular}




\begin{tabular}{|l|l|l|c|c|}
\hline No & Pernyataan & Jawaban & n & \% \\
\hline & & Jumlah & 28 & 100 \\
\hline 7. & Interaksi & 3. Cukup & 1 & 03,7 \\
& & 4. Setuju & 4 & 14,3 \\
& & 5. Sangat setuju & 21 & 75,0 \\
\cline { 3 - 5 } & & Jumlah & 28 & 100 \\
\hline
\end{tabular}

Berdasarkan .hasil uraian diatas maka media pembelajaran berbasis blog pada kompetensi rias wajah sehari-hari kelas $\mathrm{X}$ tata kecantikan kulit SMK Negeri 3 pematang siantar yang dikembangkan menunjukkan bahwa produk tersebut sangat baik.

\section{Pembahasan}

Produk pengembangan media pembelajaran interaktif pada kompetensi rias wajah sehari-hari merupakan materi pembelajaran yang telah di kembangkan dengan memperhatikan aspek pembelajaran dan dan media sebagai prinsip desain pesan pembelajaran. Penelitian pengembangan produk yang dilakukan ini diarahkan untuk menghasilkan suatu produk berupa media media pembelajaran interaktif berbasis blog pada kelas X tata kecantikan kulit semester 1 (ganjil) yang digunakan untuk meningkatkan proses pembelajaran siswa. Oleh sebab itu proses penelitian ini dilakukan dan diawali dengan: 1) studi pendahuluan, 2) kemudian mendesain media pembelajaran, 3) malakukan validasi produk dan melakukan revisi dan penyempurnaan berdasarkan analisis data validasi dari ahli materi, 4) ahli media pembelajaran dan uji coba lapangan sehingga dihasilkan media yang layak digunakan sesuai karakteristik bidang studi dan siswa sebagai pengguna.

Aspek yang direvisi dan disempurnakan berdasarkan analisis data dan uji coba serta masukan dari ahli materi, ahli media dan siswa selaku pengguna media pembelajaran interaktif ini, bertujuan untuk menggali beberapa aspek yang lazim dalam proses pengembangan suatu produk. Berikut hasil rangkuman persentase rata-rata hasil penilaian terhadap media pembelajaran interaktif kompetensi rias wajah sehari-hari oleh ahli materi, ahli media dan uji coba lapangan dapat dilihat pada tabel 7 .

Tabel 7. Rangkuman persentase rata-rata hasil penilaian terhadap mediapembelajaran interaktif berbasis blog jurusan tata kecantikan kulit

\begin{tabular}{|l|l|c|c|}
\hline No & Responden & $\begin{array}{c}\text { Persentase } \\
\text { Rata-rata }\end{array}$ & Kriteria \\
\hline 1 & Ahli materi & $94,66 \%$ & $\begin{array}{c}\text { Sangat } \\
\text { Baik }\end{array}$ \\
\hline 2 & $\begin{array}{l}\text { Ahli media } \\
\text { pembelajaran }\end{array}$ & $93,00 \%$ & $\begin{array}{c}\text { Sangat } \\
\text { Baik }\end{array}$ \\
\hline 3 & $\begin{array}{l}\text { Siswa pada uji } \\
\text { coba lapangan }\end{array}$ & $90,27 \%$ & $\begin{array}{c}\text { Sangat } \\
\text { Baik }\end{array}$ \\
\hline & Rata-rata & $92,65 \%$ & $\begin{array}{c}\text { Sangat } \\
\text { Baik }\end{array}$ \\
\hline
\end{tabular}

Beberapa kegunaan dan manfaat dalam penggunaan media pembelajaran berbasis blog pada kompetensi rias wajah sehari-hari adalah: 1) materi mudah dipahami karena konsep yang disajikan direncanakan untuk mempermudah siswa dan sistematis, 2) belajar menjadi lebih cepat dan menarik sehingga tidak menimbulkan kebosanan karena dilengkapi dengan gambargambar dan animasi serta soal latihan yang bervariasi, 3) adanya kesempatan dalam menjawab soal pada test, jika jawaban dianggap salah dengan tujuan agar siswa dapat memahami materi yang telah dipelajari, 5) media pembelajaran interaktif ini juga dapat digunakan sebagai alternative media pembelajaran secara konvensional maupun individual.

Penggunaan media pembelajaran interaktif memungkinkan siswa untuk lebih mudah memahami kompetensi rias wajah sehari-hari karena dari media pembelajaran ini memungkinkan para siswa untuk berinteraksi langsung, memiliki gambar-gambar, animasi, musik, dan soal interaktif, sehingga setiap siswa tidak kesulitan lagi membayangkan dalam hal membaca karena didalam media ini telah dijelaskan secara detail. Selain itu, media pembelajaran ini sangat praktis karena siswa dapat mempelajari materi yang terdapat di dalam media pembelajaran ini di rumah maupun menggunakan ponsel apabila memiliki jaringanj internet. Media ini juga dapat menguji kemampuan dan pemahaman siswa secara langsung melalui test atau soal pilihan berganda yang memiliki durasi waktu dan kunci jawaban yang benar, sehingga siswa dapat mengetahui 
kesalahan yang telah dilakukan dalam mengerjakan soal latihan tersebut.

\section{PENUTUP \\ Simpulan}

Berdasarkan hasil penelitian ini dapat disimpulkan sebagai berikut: (1) Ahli materi pembelajaran menunjukan bahwa: (a) kualitas materi pembelajaran dinilai sangat baik dengan persentase rata-rata sebesar $90 \%$, (b) kualitas penyajian pembelajaran dinilai sangat baik dengan persentase rata-rata sebesar $98 \%$, dan (c) kualitas kebahasaan dinilai sangat baik dengan persentase rata-rata sebesar $96 \%$. Dengan demikian media pembelajaran interaktif berbsasis blog pada kompetensi rias wajah sehari-secara keseluruhan termasuk dalam kategori "sangat baik", (2) Ahli media pembelajaran menyatakan (a) kualitas penyajian media pembelajaran dinilai sangat baik dengan persentase nilai $92 \%$, dan (b) kualitas desai media pembelajaran dinilai sangat baik dengan persentase nilai 94\%, (3) Berdasarkan uji coba lapangan aspek kualitas materi pembelajaran dinilai dengan persentase rata-rata sebesar $88,66 \%$ dan aspek tampilan media pembelajaran dinilai dengan persentase $91,88 \%$.

\section{Saran}

Berdasarkan hasil penelitian ini maka dapat disarankan:

a. Diharapkan kepada guru kompetensi rias wajah sehari-hari agar dapat menjadi fasilitator dalam pembelajaran.

b. Disarankan agar menggunakan media pembelajaran blog yang dapat meningkatkan hasil belajar siswa.

\section{DAFTAR PUSTAKA}

Anderson L. 2010. Kerangka Landasan Untuk Pembelajaran, Pengajaran dan Asesmen. Jakarta. Pustaka Belajar

Anderson R. 1987. Pemilihan dan Pengembangan Media Untuk Pembelajaran. Jakarta. PAU-UT.

Arief S, dkk. 2006. Media Pendidikan, Pengertian, Pengembangan dan Pemanfaatanya. Jakarta. Raja Grafindo Persada.

Arsyad A. 2005. Media Pembelajaran. Jakarta. Raja Grafindo Persada.

Astati S. 1995. Rias Wajah Sehari-hari. Jakarta. Karya Nusantara.

Borg R W. 1989. Educational Research An Introduction. Fifth Edition. Longman.
Dayton K. 1985. Planning and Production Instruktional Media. New York. HP Publisher.

Departemen Pendidikan Nasional. 2004. Undang Undang Sistem Pendidikan Nasional. Jakarta. Depdiknas.

Departemen Pendidikan Nasional. 2005. Kamus Besar Bahasa Indonesia. Jakarta. Balai Pustaka.

Garlach E. 2011. Media Pembelajaran. Jakarta. Rhineka Cipta.

Hamalik O. 2005. Kurikulim dan Pembelajaran. Jakarta. Bumi Aksara.

Hakim N. 1998. Perawatan Kulit Secara Terampil. Jakarta. Bumi Aksara.

Kindaro A. 2006. Cara Membuat Blog Profesional. Jakarta. Cosmics Book.

Kustanti H, dkk. 2008. Tata Kecantikan Kulit Direktorat Pengembangan SMK. Jakarta. Depdiknas.

Mahendra J. 2010. Pengembangan Media Pembelajaran Berbasis Blog Pada Mata Pelajaran Teknologi Informasi dan Komunikasi Kelas VII SMP Negeri Sukasada. Bali. FKIP Universitas Udayana.

Muchtar A. 2006. Pendidikan Nilai Moril dalam Dimensi Pendidikan. Bandung. PKN UPI.

Putra R. 2009, Cara Mudah Membuat Blog dan Face Book. Yogyakarta. Cosmics Book.

Sadiman A, dkk. 1986. Media Pendidikan dan Pengembangan. Jakarta. Pustekkom.

Satyasa I. 2007. Metodologi Penelitian Tindakan Kelas. Singaraja. Ganesha.

Sugiyono. 2007. Metode Penelitian Kuantitatif, Kualitatif, R\&D, Bandung. Alfabeta.

Sukiman. (2012) Pengembangan Media Pembelajaran. Yogyakarta. Pustaka Insan Madani.

Tirtarahardja U. 2005. Pengantar Pendidikan.

Jakarta. Rhineka Cipta. 